\title{
CHARACTERIZATION, CLASSIFICATION AND LAND USE MANAGEMENT OF FLOOD PLAIN SOILS OF CENTRAL CROSS RIVER STATE, NIGERIA.
}

\author{
M. E. NSOR AND F. O. R. AKAMIGBO
}

(Received 19 November, 2008; Revision Accepted 19 February, 2009)

\section{ABSTRACT}

The floodplain soils of Central Cross River State are extensively cultivated for food crop production and contributes nearly $60 \%$ of the agricultural wealth of the inhabitants. Knowledge of their characteristics, classification and management will enhance their productive potential and facilitate technological transfer. Profile pits were escavated in levee and backswamp locations in two communities with extensive floodplains and studied. Based on morphological and other analytical characteristics, the soils were classified according to USDA soil Taxonomy and correlated to FAO/UNESCO soil map of the world legend. Backswamp soils were classified as Vertic Tropaquepts while levee soils were classified as Typic Tropustuepts at sub-group level of the USDA soil Taxonomy. The FAO/UNESCO equivalent of these soils is Luvisol. The major limitations of these soils are high acidity (low pH), low available phosphorus and poor drainage. Backswamp soils were superior in most fertility indices assessed than levee soils. Soil $\mathrm{pH}$ in these soils had a high positive correlation with CEC, available phosphorous and base saturation with " $r$ " values of $0.79,0.76$, and 0.75 at $p<0.01$ respectively. However, the relationship between CEC and erodibility index was negative with " $r$ " value of -0.77 at $p>0.01$ significant level. The floodplain soils can be efficiently managed through the use of water control mechanisms, construction of efficient low cost drainage systems, construction of giant heaps and application of phosphatic fertilizers/NPK high in phosphorus. The backswamps can be dammed for fish farming.

KEYWORDS: Floodplain soils, classification, land use, sustainable management.

\section{INTRODUCTION}

There is an increasing need to provide more information on our wetlands especially the floodplains because of their enormous agricultural potentials. Floodplains soils are derived from alluvial deposits and are located in areas that are susceptible to flooding during the wet season and are somewhat well drained during the dry season (Carsky, 1992). Eshett (1993) remarked that the largest concentration of natural wetland occurs in Southern Nigeria where the principal geological formation consists of coastal plain sands and alluvium. Floodplains are areas within which river escapes into during flooding. These soils may be sandy as in beach deposit or derived from sandstone, but are more frequently clayey and are said to be very fertile with maximum water holding capacity (William et al., 1979). Brinkman and Blockhuis (1986) observed the texture of floodplain soils to range from clay to sand with the greatest variation in the texture of surface horizons. World Bank (1992) described the floodplain as flood prone, low lying slow draining area, that generally posses finer texture. Most flood plain soils are seasonally flooded.

Troech and Thompson (1993) observed that floodplain soils that are seasonally dry possess structures that range from blocky to prismatic. Ahn (1993) remarked that well drained tropical soils are usually reddish in colour, but when drainage is poor the soil colour is either bluish grey, greenish grey or neutral grey. Evans and Framzmeier (1986) noted that floodplain soils with reducing conditions produce low chroma mottle colour while better drained soils produce brighter colours.
Floodplains are the major soil resource that contribute nearly $60 \%$ of the agricultural wealth of Central Cross River State, Nigeria, and occur extensively along the Cross River bank. Regrettably, much has not been done to highlight the characteristic potentials of this natural asset. This study is intended to investigated the characteristics of floodplain soils, highlight cost effective management strategies and classify the soils in order to facilitate transfer of knowledge or experience from one plot to another.

\section{MATERIALS AND METHODS}

\section{Site Description}

This study was carried out in Central Cross River State, Nigeria. The study area lies between longitude $8^{\circ} 00$ and $9^{\circ} 10$ and latitude $5^{\circ} 20^{\prime \prime}$ and $6^{\circ} 20^{\prime \prime} \mathrm{N}$. The geology of the area consist of cretaceous sandstone-shale intercalation and basement complex of the Eze-Aku group of the South Eastern Benue Trough and Ikom-Mamfe Embayment (Petters, 1995). The mean annual rainfall of the area ranges from $2500-3500 \mathrm{~mm}$ per annum (Bulktrade and Investment Company Limited, 1989).

\section{Sampling Design/Technique}

The stratified random sampling technique was adopted in this study. The floodplains were stratified into backswamps and levee. A total of four profile pits were excavated in the study area. Two communities with extensive floodplains were selected for this study. In each of the communities two pits, one at the backswamp and the other at the levee were excavated. The randomly selected communities were Ovonum and

M. E. Nsor, Department of Agronomy, Cross River University of Technology, Calabar, Nigeria.

F. O. R. Akamigbo, Department of Soil Science, University of Nigeria, Nsukka. Nigeria. 
Ediba in Obubra and Abi Local Government Areas respectively.

\section{Field Work}

The profile pits were dug at the most representative points of observation in each sampling location. The soil profiles were then described according to the FAO/UNESCO (1990) guidelines. Soil samples were taken from the profile for routine chemical analysis, micro nutrient analysis and determination of soil physical parameters (particle size distribution, bulk density, particle density, erodibility index).

\section{Laboratory Analysis}

The bulk density was determined by the cylindrical core method (Blake, 1965). The particle size distribution was determined by the Bouyoucos hydrometer method (Klute, 1986). Soil erodibility index was estimated by evaluating the ratio of sand and silt contents to clay content (Hudson, 1995).

The soil samples for analysis for characterization and classification were air dried, crushed and passed through a $2 \mathrm{~mm}$ mesh sized sieve. Soil pH was determined in a 1:2.5 soil: water suspension using glass electrode $\mathrm{pH}$ meter. Organic carbon was determined by the dichromate wet oxidation method of Walkley and Black (Jackson, 1969). Total Nitrogen was analysed according to the macro kjeldahl method (Jackson, 1969). Available phosphorus was extracted by the Bray No. 1 procedure (Bray and Kurtz, 1945), and estimated by the molybdenum blue colour technique (Murphy and Riley, 1962). Exchangeable cations were extracted by leaching the soil with IN ammonium acetate solution ( $\mathrm{pH} 7.0$ ). Exchangeable $\mathrm{K}$ and $\mathrm{Na}$ in the extract were determined using a flame photometer while the exchangeable $\mathrm{Ca}$ and $\mathrm{Mg}$ were determined using the versonate titration method. Exchangeable $\mathrm{H}$ and $\mathrm{Al}$ were determined by the titration method from an extract obtained using IN KCl solution (McLean, 1965). The cation exchange capacity (CEC) at $\mathrm{pH} 7$ was estimated using the $\mathrm{NH}_{4} \mathrm{OA}_{\mathrm{C}}$ method (Jackson, 1969). The micro nutrients, free iron, manganese and aluminium oxides (dithionite $\mathrm{Fe}_{2} \mathrm{O}_{3}, \mathrm{Mn}_{2} \mathrm{O}_{3}$ and $\mathrm{Al}_{2} \mathrm{O}_{3}$ ) were extracted by the dithionite-citrate-bicarbonate (DCB) solution according to the method of Mehra and Jackson (1960).

\section{RESULT AND DISCUSSION}

The soils of floodplains are derived from recent alluvial deposits, and are confined to river valleys. These soils are permanently saturated with water in the wet season but in the dry season, its moisture content is near field capacity in the sub-soil and dry in the top soil with visible cracks.

\section{Morphological Characteristics}

Under moist conditions floodplain soils are characterized by dark grey, very dark reddish grey, dark brown, reddish yellow and brown with dominant hue of 7.5 YR. Specifically soils at the backswamp positions were dark grey and reddish grey while those at the levee were dark brown, brown and yellowish brown with reddish yellow, strong brown and red mottles occurring throughout depth at the backswamps and within $50 \mathrm{~cm}$ depth at the levee. These soils are characterized with spodic, cambic and argillic clay, loam and clay loam sub-surface diagnostic horizons due to the presence of clay skins along its pores. Floodplain soils have moderate medium sub-angular blocky, weak medium granular and strong coarse prismatic structures. This structural observation collaborates the findings of Troeh and Thompson (1993) who observed that floodplain soils that are seasonally dry, posses structures that range from blocky to prismatic.

The presence of high $\mathrm{Na}^{+}$content and prismatic structures suggests the possession of natric sub-surface horizons (Ibanga, 2003). The dry consistence was hard to extremely hard, although occasional soft and slightly hard consistence occurred in surface soils of levee positions. Under moist condition, the top soils consistence were very friable and friable. The sub soils were sticky-slightly plastic to sticky-plastic (Table 1). This was due to high illuviation of clay giving rise to argillic sub-surface diagnostic horizons (Esu, 1999). Few to common, very fine, fine and medium pores dominated the pedons studied. The soils were generally characterized with deep wide cracks at the backswamp and clay skins in levee pedons. The horizon boundary were either gradual, abrupt, clear or diffuse in distinctness but were generally wavy in topography (Table 1).

\section{Physical Properties}

Sandy clay, clay, loam and clay loam were dominant textures encountered in the floodplain soils. The particle size distribution was dominated by clay and silt, followed by the fine sand fraction (Table 2). This observation collaborates the findings of Akamigbo et al. (2001) on the fadama soils of Bauchi State. Bulk density was generally lower at the surface soil than at the sub-soil. Mean values of $1.13,1.29$, and $1.58 \mathrm{~g} / \mathrm{cm}^{3}$ and 0.96 , 0.98 and $1.23 \mathrm{~g} / \mathrm{cm}^{3}$ were obtained for backswamp and levee positions at depths 0.025 and $75 \mathrm{~cm}$ respectively in the floodplain soils (Table 3 ). The increase in bulk density with soil depth is due solely to elluviationilluviation process which fills up coarser pores (Ogban and Ekerette, 2001). Higher values of bulk density were observed at the backswamp with lower values at the levee. This is due to the increased clay content with few fine pores at the backswamp.

Values of soil erodibility index averaged 0.9 at the backswamp and 1.8 at the levee. The levee had higher erodibility index than the backswamp, thus backswamp soils are less susceptible to erosion. This is due to variation in clay content and topographic attributes between the levee and the backswamps. This finding agrees with the work of Hudson (1995) who remarked that soil properties such as texture, structure and porosity as well as topographic features of slope length and slope angle affect erodibility of soil. 
Table 1: Morphological Characteristics of Representatives pedons of soils of floodplain soils of Central Cross River State, Nigeria.

\begin{tabular}{|c|c|c|c|c|c|c|c|c|c|c|c|c|}
\hline \multirow[t]{2}{*}{$\begin{array}{c}\text { Sample No. } \\
\text { (9) }\end{array}$} & \multirow[t]{2}{*}{$\begin{array}{c}\text { Horizon } \\
\text { Designation }\end{array}$} & \multirow{2}{*}{$\begin{array}{c}\text { Horizon } \\
\text { Thick } \\
\text { ness }\end{array}$} & \multirow[t]{2}{*}{$\begin{array}{l}\text { Major colour } \\
\text { (1) }\end{array}$} & \multirow[t]{2}{*}{$\begin{array}{l}\text { Mottles } \\
(2)\end{array}$} & \multirow[t]{2}{*}{$\begin{array}{c}\text { Texture } \\
\text { (3) }\end{array}$} & \multirow[t]{2}{*}{$\begin{array}{c}\text { Structure } \\
(4)\end{array}$} & \multicolumn{3}{|c|}{$\begin{array}{c}\text { Consistence } \\
\text { (5) }\end{array}$} & \multirow[t]{2}{*}{$\begin{array}{l}\text { Roots } \\
(6)\end{array}$} & \multirow[t]{2}{*}{$\begin{array}{l}\text { Pores } \\
\text { (7) }\end{array}$} & \multirow{2}{*}{$\begin{array}{c}\text { Horizon } \\
\text { Boundary } \\
(8)\end{array}$} \\
\hline & & & & & & & Dry & Moist & Wet & & & \\
\hline ED/ALU/A/1 & Ape & $0-10$ & 7.5YR4/1; Dg & 7.5YR6/6; ffd, Ry & $\mathrm{SC}$ & $2 \mathrm{M} \mathrm{sbk}$ & $\mathrm{vh}$ & $\mathrm{fr}$ & s-sp & $\mathrm{mf}$ & cf & aw \\
\hline ED/ALU/A/2 & $\mathrm{Ba}$ & $10-35$ & 7.5YR3/1; vdg & 7.5YR5/6; cmd Sb & $\mathrm{C}$ & $\begin{array}{c}3 \mathrm{C} \\
\text { prismatic }\end{array}$ & vh & $f$ & $s-p$ & fvf & $\mathrm{ff}$ & gw \\
\hline ED/ALU/A/3 & Bag & $35-86$ & 7.5YR5/1;G & 7.5YR4/6; cmb, Sb & $\mathrm{C}$ & $\begin{array}{c}3 \mathrm{C} \\
\text { prismatic }\end{array}$ & eh & $f$ & vs-p & fvf & fvf & $g w$ \\
\hline ED/ALU/A/4 & Bhg & $86-130$ & 7.5YR5/1;G & 7.5YR4/6; mcp, Sb & C & $3 \mathrm{M} \mathrm{sbk}$ & eh & vf & $v s-p$ & fvf & $\mathrm{fm}$ & \\
\hline OV/ALU/A/1 & Ape & $0-18$ & 7.5YR4/1; Dg & 5YR6/8; fff, Lr & $\mathrm{C}$ & $\begin{array}{c}1 \mathrm{M} \\
\text { granular }\end{array}$ & $\mathrm{s}$ & vfr & ss-sp & cf & $\mathrm{cm}$ & $\mathrm{cW}$ \\
\hline OV/ALU/A/2 & $\mathrm{Bi}$ & $18-48$ & 7.5YR5/1; G & 2.5YR4/8;ffd, R & $\mathrm{C}$ & $2 \mathrm{M} \mathrm{sbk}$ & sh & $\mathrm{fr}$ & ss-p & cf & $\mathrm{cm}$ & $\mathrm{CW}$ \\
\hline OV/ALU/A/3 & Bag & $48-65$ & 5YR5/1;Rg & 2.5YR4/8;cmd, R & C & $2 \mathrm{M} \mathrm{sbk}$ & $\mathrm{h}$ & $f$ & ns-np & fvf & fvf & gw \\
\hline OV/ALU/A/4 & Bhg & $65-118$ & 2.5YR6/1; Rg & 2.5YR4/8; cmp, R & $\mathrm{C}$ & $2 \mathrm{M} \mathrm{skb}$ & $\mathrm{vh}$ & $\mathrm{f}$ & $s-p$ & fvf & $\mathrm{ff}$ & \\
\hline ED/ALU/B/1 & Ap & $0-12$ & 7.5YR4/6; Sb & & L & $\begin{array}{c}1 \mathrm{M} \\
\text { granular }\end{array}$ & $\mathrm{s}$ & vfr & ss-sp & $\mathrm{mf}$ & $\mathrm{cm}$ & aw \\
\hline ED/ALU/B/2 & B & $12-41$ & 7.5YR4/4; B & & L & $2 \mathrm{M} \mathrm{sbk}$ & sh & vfr & ss-p & $\mathrm{ff}$ & $\mathrm{cm}$ & gw \\
\hline $\mathrm{ED} / \mathrm{ALU} / \mathrm{B} / 3$ & Bhg & $41-80$ & 7.5YR6/6; Ry & 5YR4/6; fff, R & $\overline{C L}$ & $3 \mathrm{M} \mathrm{sbk}$ & $\mathrm{h}$ & $\mathrm{f}$ & ss-p & fvf & $\mathrm{mm}$ & gw \\
\hline $\mathrm{ED} / \mathrm{ALU} / \mathrm{B} / 4$ & $\mathrm{Btg}_{1}$ & $80-130$ & 7.5YR6/8; Ry & 5YR4/6; cmd, R & $\mathrm{CL}$ & $3 \mathrm{M} \mathrm{sbk}$ & $\mathrm{h}$ & $f$ & $s s-p$ & fvf & $\mathrm{mm}$ & gw \\
\hline ED/ALU/B/5 & $\mathrm{Btg}_{2}$ & $\begin{array}{c}130- \\
170\end{array}$ & 7.5YR4/6; Ry & 7.5YR6/6; cff, Ry & $\mathrm{C}$ & $3 \mathrm{M} \mathrm{sbk}$ & $\mathrm{vh}$ & $f$ & $s-p$ & fvf & $\mathrm{cm}$ & \\
\hline OV/ALU/B/1 & Ap & $0-19$ & 7.5YR3/2; Db & & $\mathrm{CL}$ & IF crumb & $\mathrm{s}$ & vfr & ss-sp & $\mathrm{ff}$ & $\mathrm{cf}$ & $\mathrm{cW}$ \\
\hline OV/ALU/B/2 & $A B$ & $19-53$ & 7.5YR4/4; B & & $\mathrm{CL}$ & IF crumb & $\mathrm{s}$ & $\mathrm{fr}$ & ss-sp & fvf & $\mathrm{mf}$ & qw \\
\hline OV/ALU/B/3 & $\mathrm{Btg}_{1}$ & $53-80$ & 7.5YR4/4; B & & $\mathrm{CL}$ & $2 \mathrm{M} \mathrm{sbk}$ & $\mathrm{vh}$ & $\mathrm{fr}$ & ss-sp & $\mathrm{cf}$ & $\mathrm{mm}$ & $\mathrm{cW}$ \\
\hline OV/ALU/B/4 & $\mathrm{Btg}_{2}$ & $80-139$ & 7.5YR4/4; B & & $\mathrm{CL}$ & $3 \mathrm{M} \mathrm{sbk}$ & $\mathrm{vh}$ & $\mathrm{fr}$ & $s-p$ & $\mathrm{cf}$ & $\mathrm{fm}$ & $d w$ \\
\hline OV/ALU/B/5 & $\mathrm{Btg}_{3}$ & $\begin{array}{c}139- \\
174\end{array}$ & 7.5YR4/2; B & 2.5YR5/6; cfd, R & $\mathrm{C}$ & $3 \mathrm{M} \mathrm{sbk}$ & $\mathrm{vh}$ & ff & $s-p$ & fvf & $\mathrm{fm}$ & \\
\hline
\end{tabular}

KEY:

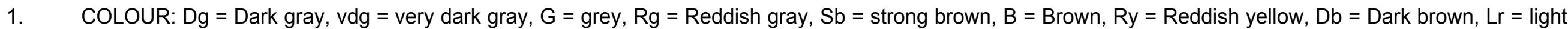
red, $\mathrm{R}=$ red.

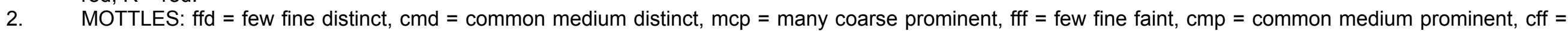
common fine faint, cfd = common fine distinct.

3. TEXTURE: $\mathrm{SC}=$ sandy clay, $\mathrm{C}=$ clay, $\mathrm{L}=$ loam, $\mathrm{CL}=$ clay loam.

4. STRUCTURE: 1 = weak, $2=$ moderate, $3=$ strong, $\mathrm{F}=$ fine, $\mathrm{M}=$ medium, $\mathrm{C}=$ coarse, sbk = sub- angular blocky.

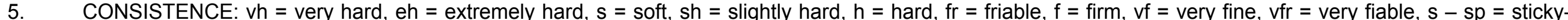
slightly plastic, $s-p=$ sticky plastic, vs $-p=$ very sticky-plastic, $s s-s p=$ slightly sticky-slightly plastic, $s s-p=$ slightly-stick-plastic, ns-np = non sticky, non plastic. ROOTS: $\mathrm{mf}=$ many fine, $\mathrm{fvf}=\mathrm{few}$ very fine, $\mathrm{cf}=\mathrm{mmon}$ fine, $\mathrm{ff}=$ few fine.

PORES: $\mathrm{cf}=$ common fine, $\mathrm{ff}=$ few fine, $\mathrm{fvf}=$ few very fine, $\mathrm{fm}=$ few medium, $\mathrm{cm}=$ common medium, $\mathrm{mm}=\mathrm{medium}, \mathrm{mf}=\mathrm{many}$ fine

BOUNDARY: aw = abrupt wavy, gw = gradual wavy, cw = clear wavy, $d w$ = diffuse wavy

9. $\mathrm{A}=$ Backswamp, $\mathrm{B}=$ Levee, $\mathrm{ED}=\mathrm{Ediba}, \mathrm{OV}=$ Ovonum 


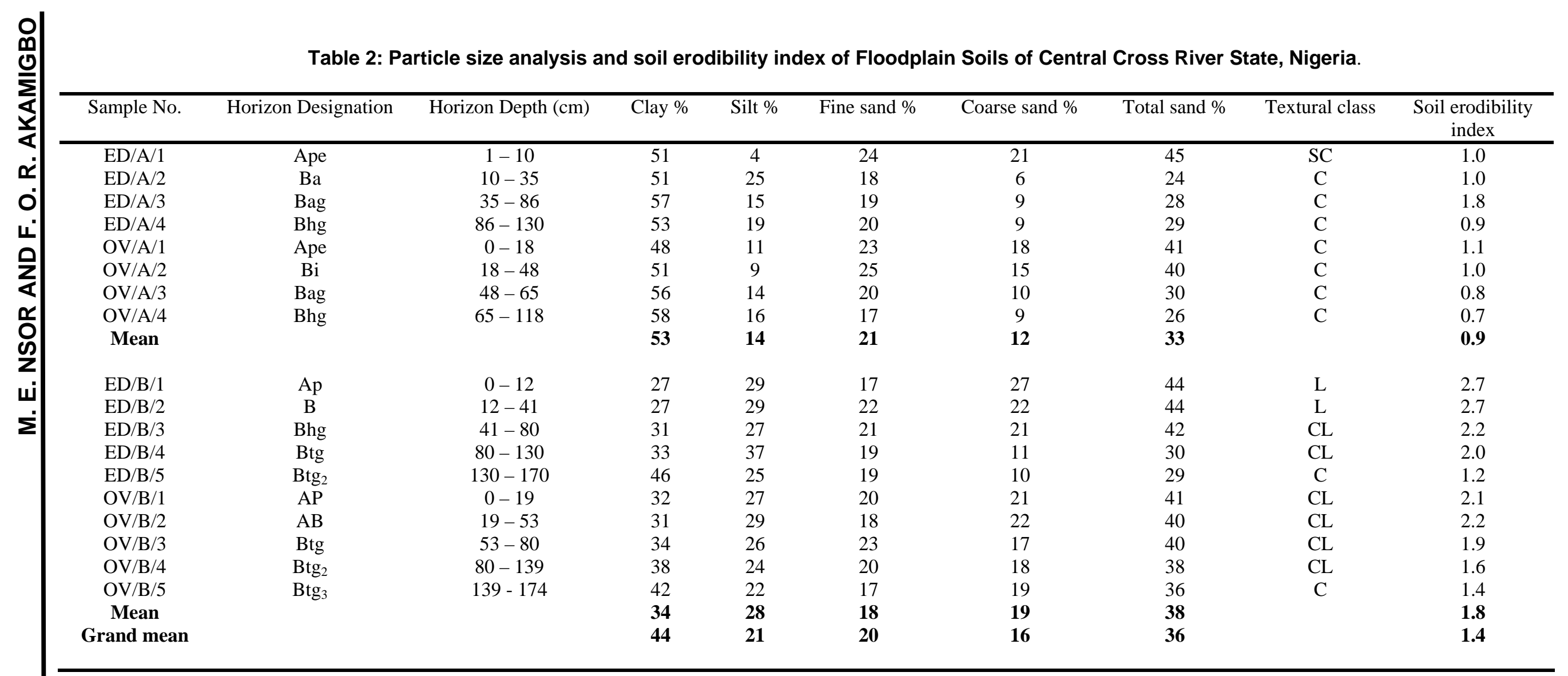

Key: SC = Sandy clay, $C=$ Clay, $L=$ Loam, $C L=$ Clay loam, ED = Ediba, OV = Ovonum, A = Backswamp, B = Levee. 
Table 3: Bulk and particle densities at specified depths of floodplain soils of Central Cross River State.

\begin{tabular}{lcccccc}
\hline & \multicolumn{3}{c}{ Bulk Density $\mathbf{( \mathbf { g } / \mathbf { c m } ^ { 3 } )}$ Particle density $\mathbf{( g / \mathbf { c m } ^ { 3 } )}$} \\
& Ocm & $25 \mathrm{~cm}$ & $75 \mathrm{~cm}$ & $0 \mathrm{~cm}$ & $25 \mathrm{~cm}$ & $75 \mathrm{~cm}$ \\
\hline OV/A & 1.27 & 1.31 & 1.60 & 2.54 & 2.62 & 3.20 \\
ED/A & 0.99 & 1.26 & 1.55 & 1.98 & 2.52 & 3.10 \\
Mean & 1.13 & 1.29 & 1.58 & 2.26 & 2.57 & 3.15 \\
& & & & & & \\
OV/B & 0.99 & 0.85 & 1.24 & 1.98 & 1.70 & 2.48 \\
ED/B & 0.93 & 1.10 & 0.99 & 1.86 & 2.20 & 1.98 \\
Mean & 0.96 & 0.98 & 0.12 & 1.92 & 1.95 & 2.23 \\
Grand mean & 1.05 & 1.14 & 1.35 & 2.09 & 2.26 & 2.69 \\
SD & 0.13 & 0.18 & 0.25 & 0.26 & 0.36 & 0.49 \\
CV \% & 12.6 & 15.8 & 18.3 & 12.7 & 15.9 & 18.4 \\
SE \pm & 0.07 & 0.09 & 0.13 & 0.13 & 0.18 & 0.25 \\
\hline
\end{tabular}

KEY: A = Backswamp, B = Levee, ED = Ediba, OV = Ovonum

\section{Chemical Characteristics}

The soil reaction in the floodplain soils ranged from $\mathrm{pH} 3.9-5.5$ averaging 4.9 and 4.3 rated very strongly acid and extremely acid for backswamps and levees respectively. Values of organic carbon ranged from $5.9-23.4 \mathrm{~g} / \mathrm{kg}$ averaging $13.3 \mathrm{~g} / \mathrm{kg}$ and $13.0 \mathrm{~g} / \mathrm{kg}$ and rated medium for both backswamp and levee topographic positions respectively. Total nitrogen ranged from $0.4-2.4 \mathrm{~g} / \mathrm{kg}$ averaging $1.1 \mathrm{~g} / \mathrm{kg}$ at both backswamp and levee position of the floodplains. These values were rated medium.

Among the exchangeable cations, sodium ranged from $0.18-0.24 \mathrm{cmol} / \mathrm{kg}$ averaging $0.22 \mathrm{cmol} / \mathrm{kg}$ and rated medium for both backswamps and levee. Exchangeable potassium ranged from $0.05-0.49$ $\mathrm{cmol} / \mathrm{kg}$ averaging 0.31 and $0.11 \mathrm{cmol} / \mathrm{kg}$ and rated high for backswamps and low for levee positions. The high $\mathrm{K}$ value at the backswamps may be due to the increased organic matter deposition. This agree with the findings of De-Alwis and Pluth (1976), who remarked that organic matter content enhances the adsorption of cations.

Exchangeable calcium ranged from $0.8-19.1$ $\mathrm{cmol} / \mathrm{kg}$ averaging 15.2 and $2.5 \mathrm{cmol} / \mathrm{kg}$ and rated high for backswamps and medium for levee. The high calcium value at the backswamp is the direct consequence of enhance deposition of organic matter and weathered materials from basement complex rocks, high in basic cations and occurring around the upper course of cross river. This observation collaborates the findings of Akamigbo et al., (2001).

Exchangeable Magnesium values ranged from $1.2-13.2 \mathrm{cmol} / \mathrm{kg}$ averaging 10.5 and $2.2 \mathrm{cmol} / \mathrm{kg}$ rated high for backswamp soils and low for levees. This result agrees with the findings or Raji et al., (2001) who reported that magnesium is generally moderate in content but high in the backswamp soils.

Cation exchange capacity values ranged from $2.5-33.0 \mathrm{cmol} / \mathrm{kg}$ averaging $26.2 \mathrm{cmol} / \mathrm{kg}$ at the backswamp soils and $5.0 \mathrm{cmol} / \mathrm{kg}$ at the levees. Cation exchange capacity are high in the backswamp soils and low at the levees soils. The high cation exchange capacity at the backswamp is due to the increased clay and organic matter contents. The high CEC values of the backswamp collaborates the findings of Esu (1989) for some alluvial soils in Nigeria.
Values of available phosphorus ranged from 5.0 - $38.8 \mathrm{mg} / \mathrm{kg}$ averaging $16.4 \mathrm{mg} / \mathrm{kg}$ for the backswamps and $12.4 \mathrm{mg} / \mathrm{kg}$ for levee soils. These values are rated medium for both backswamp and levee soils. However top soils of floodplains had high values of available phosphorus (Table 4). This may be due to increased organic matter deposition and mineralization in the floodplain soils.

Base saturation in the floodplain soils ranged from $31.0-97.1 \%$ averaging $89.1 \%$ for backswamps and $42.2 \%$ for levee soils. These values are rated high for backswamp soils and low for levee soils.

Floodplain soils exhibit moderate to high levels of dithionite $\mathrm{Fe}$ and $\mathrm{Al}$ oxides especially in the dry season (Table 5). Values of $\mathrm{Fe}_{2} \mathrm{O}_{3}, \mathrm{Al}_{2} \mathrm{O}_{3}$ and $\mathrm{Mn}_{2} \mathrm{O}$ averaged $28.4,4.5$, and $9.0 \mathrm{~g} / \mathrm{kg}$; and $2.4,0.5$ and $0.2 \mathrm{~g} / \mathrm{kg}$ for backswamp and levee soils respectively. This finding agrees with the observation of Mohr et al., (1972) who remarked that hydromorphic soils are usually enriched with $\mathrm{Fe}$ due to deposition of $\mathrm{Fe}$ compound. Consequently the very poorly drained status of backswamps increases their micronutrient status compared to levee and other upland soils.

\section{Correlation in floodplain soils}

The relationship between $\mathrm{pH}\left(\mathrm{H}_{2} \mathrm{O}\right)$ and cation exchange capacity, available phosphorus and base saturation were linear positive with high correlation coefficients " $r$ " of $0.79,0.76$ and 0.75 , all at $(p<0.01)$ respectively. Organic carbon had a high positive linear relationship with total nitrogen and available phosphorus with correlation coefficient " $r$ " of 0.93 and 0.76 respectively. Cation exchange capacity had a high positive linear relationship with soil $\mathrm{pH}$, base saturation and clay content with correlation coefficient " $r$ " of 0.79 , 0.97 and 0.82 at $P<0.01$, the relationship between CEC and erodibility index was negative with " $r$ " value of -0.77 $(P>0.01)$. This implies that as CEC increases, soil erodibility index decreases. Soils with low erodibility index have high CEC. The relationship between erodibility index and CEC, base saturation and clay content was high negative with correlation coefficient " $r$ " of -0.77 , and -0.98 at $\mathrm{P}>0.01$ respectively. 
Table 5: Dry Season Mean Values of Dithionite Extractable $\mathrm{Fe}_{2} \mathrm{O}_{3}, \mathrm{Mn}_{2} \mathrm{O}_{3}$ and $\mathrm{Al}_{2} \mathrm{O}_{3}$ of Representative pedons of Floodplain Soils of Central Cross River State, Nigeria.

\begin{tabular}{cccc}
\hline Pedon & $\mathrm{Fe}_{\mathbf{2}} \mathbf{O}_{\mathbf{3}}$ & $\mathbf{M n}_{\mathbf{2}} \mathbf{O}_{\mathbf{3}}$ & $\mathrm{Al}_{\mathbf{2}} \mathbf{0}_{\mathbf{3}}$ \\
\cline { 4 - 4 } & & $\mathbf{g} / \mathbf{k g}$ & \\
\cline { 2 - 4 } & 20.2 & 8.4 & 0.4 \\
ED/A & 36.6 & 9.6 & 0.6 \\
OV/A & 28.4 & 9.0 & 0.5 \\
Mean & 3.7 & 2.8 & 0.2 \\
ED/B & 5.3 & 1.9 & 0.1 \\
& 4.5 & 2.4 & 0.2 \\
Mean & 16.5 & 5.7 & 0.3 \\
Grand mean & 80.57 & 59.07 & 63.33 \\
CV\% & 0.67 & 1.69 & 0.10 \\
SE \pm & & &
\end{tabular}

KEY: $\mathrm{A}=$ Backswamp, $\mathrm{B}=$ Levee, $\mathrm{ED}=$ Ediba, $\mathrm{OV}=$ Ovonum

\section{Taxonomic classification of flood plain soils}

The soils under investigation were classified according to the USDA soil taxonomy (Soil Survey Staff, 1994) and correlated with the FAO/UNESCO legend of World Reference Base (WRB) system (FAO/UNESCO, 1974). The low $\mathrm{pH}$, high cation exchange capacity (High fertility), presence of argillic, spodic and cambic subsurface diagnostic horizons, existence of poorly developed horizons as evident in the absence of $\mathrm{C}$ horizons of the flood plain soils, qualified classifying these soils as inceptisols (Soil Survey Staff, 1994). The soils of the back swamps occur under aquic soil moisture regime with a hyperthermic soil temperature regime, hence these soils can be classified as Aquepts at the sub-order level. Their occurrence under tropical climatic conditions permits their placement as tropaquepts in the great group level. In view of their characteristic fine texture and cracking nature, backswamp soils can be classified at the sub-group level as Vertic Tropaquepts. The levee soils occur under ustic moisture regime with a hyperthermic temperature regime hence these soils can be classified as ustuepts in the sub-order level. Their occurrence under tropical conditions and wide spread status in Central Cross River State, enables the levee soils to be classified Typic Tropustuepts at the sub-group level. The Federal Department of Agricultural Land Resources (FDALR, 1990) classified similar soils as Fluvepts or inceptisols. The FAO/UNESCO legend or World Reference Base system classification of Vertic Tropaquepts and Typic Tropustuepts is Luvisol.

\section{CONCLUSION}

Flood plain soils are unique in their characteristics. These unique attributes are greatly influenced by the dynamic nature of their water table, depositional and mineralization pattern. The backswamp soils are superior in most of the fertility indices assessed and thus are more fertile than the levee soils. The productive potentials of the flood plain soils can be enhanced through the installation of adequate drainage systems and cultivation of water tolerant crops like swamp rice in rainy seasons. Adequate liming and application of phosphatic or NPK fertilizers are also recommended.

\section{REFERENCES}

Ahn, P. M. 1993. Tropical soils and fertilizer use. Longman and Scientific Technical, United Kingdom, 264pp.

Akamigbo, F. O. R., Ezedinma, F. O. C. and Igwe, C. A., 2001. Properties and classification of some Fadama soils of Bauchi State, Nigeria, proceedings of the $27^{\text {th }}$ Annual conference of the Soil Science Society of Nigeria, held at Calabar (45-51).

Blake, G. R., 1965. Bulk Density In: Methods of Soil Analysis, C. A. Black (ed). American Society of Agronomy, 9: $374-390$.

Bray, R. H. and Kurtz, L. T., 1945. Determination of total, organic and available forms of phosphorus. Soil Science, 59: $45-49$.

Brinkman, R. and Blockhuis, W. A., 1986. The Wetlands and Rice in sub-saharan Africa, Nigeria pp. 31 42.

Bulktrade and Investment Company Limited, 1989. Soil and land use Survey of Cross River State, Main Report, Ministry of Agriculture and Natural Resources, Cross River State, Nigeria.

Carsky, R. J. 1992. Rice based Production in inland valleys of West Africa. Research Review and Recommendation, International Institute of Tropical Agriculture, Ibadan, pp. $18-38$.

De-Alwis, K. A. and Pluth, D. J., 1976. The red latosols of Sri Lanka: Macro-morphological, Physical and Chemical properties, Genesis and classification. Soil Science of American Journal; 40: 912 - 920.

Eshett, E. T., 1993. The wetland soils of Nigeria properties, Classification and Traditional Landuse Practices, Wetlands and Ecotones: studies on Land-Water Interactions, pp. 227 244. 
Esu, I. E. 1989. A pedological characterization of soils of the Hadejia alluvial complex in the semi-arid region of Nigeria. Pedo logie xxxix: $171-190$.

Esu, I. E. 1999. Fundamentals of pedology, StirlingHorden Publishers (Nig.)Limited, Ibadan, 136pp.

Evans, C. V. and Framzmeier, D. P., 1986. Saturation, Aeration and colour pattern in a Toposequence of soils in North Central Indiana. Soil Science Society of American Journal, 50: 975 - 980.

FAO/UNESCO, 1974. FAO/UNESCO Soil map of the World, 1:5000000, Vol. 1 legend, FAO, Rome, 79pp.

FAO/UNESCO, 1990. Soil map of the World Legend, World Soil Resources Report, FAO, Rome, $119 p p$.

Federal Department of Agricultural Land Resources (FDALR) 1990. Soil Report: The Reconnaissance Soil Survey of Nigerian, Chukason Nigeria Limited, Jos- Nigeria.

Hudson, N. 1995. Soil conservation. BT Balsfoed Limited, London.

Ibanga, I. J. 2003. Guidelines for Soil Survey, Classification and Land use, De-Rio Press Nigeria Limited, Calabar - Nigeria.

Jackson, M. L., 1969. Soil Chemical Analyis: Advance Course $\left(2^{\text {nd }}\right.$ ed.), United State Department of Agriculture (217 - 224) America.

Klute, A. 1986. Methods of soil Analysis. Physical and Mineralogical Properties. American society of Agronomy, Madison, Wisconsin.

McLean, E. O., 1965. Aluminium In: C. A. Black (ed) Methods of Soil Analysis, American Society of Agronomy, Madison, Wisconsin.
Mehra, O. P. and Jackson, M. L., 1960. Iron oxide Removal, from soils and clays by a dithionite citrate system buffered with sodium bicarbonate, Clay Mineralogy, 7: $317-327$.

Murphy, I. and Riley, J. P, 1962. A modified single solution method for the determination of phosphorus in natural waters. Analytical Chemist, 27: $31-36$.

Ogban, I. I. and Ekerette, I. P., 2001. Physical and chemical properties of the coastal plains and soil of the south Eastern Nigeria. Nigeria Journal of Soil Research, 2: $21-31$.

Petter, S. W. 1995. South Eastern Benue Trough and Ikom-Mamfe Embayment, In: Geological Excursion Guide Book (26 - 36), Dec-Ford Publishers Limited, Calabar.

Raji, B. A., Malgwi, W. B., Falaki, A. M. and Kparmwang, T., 2001. Characterization and classification of soils of the Jangari Alluvial complex in the semi-Arid region of Nigeria, proceedings of the $27^{\text {th }}$ Annual conference of the soil science society of Nigeria, held at Calabar.

Soil Survey Staff, 1994. Keys to soil Taxonomy, USDA soil conservation service $\left(6^{\text {th }}\right.$ ed.), $306 \mathrm{pp}$.

Troeh, E. and Thompson, L. M., 1993. Soil and Soil Fertility $\left(5^{\text {th }}\right.$ ed.) Oxford University Press, New York. $354 p p$.

William, C. N., Rajarathan, J. N. and Chew, W. Y., 1979.

Tree and Field Crops of the Wetter Region of the

Tropics: An Intermediate Tropical Agricultural Series, $130 p p$.

World Bank, 1992. Staff Appraisal Report, National Fadama Development Project, Kano-Nigeria 